Check for updates

The BMJ

kabbasi@bmi.com Follow Kamran on Twitter@KamranAbbasi Cite this as: $B M / 2020 ; 370: m 3714$ http://dx.doi.org/10.1136/bmj.m3714 Published: 24 September 2020

\title{
Covid-19: The fatal attraction of herd immunity
}

\section{Kamran Abbasi executive editor}

Scientists are in dispute. ${ }^{1}$ There is nothing new in this. Debate is to be encouraged-truth is nuanced $^{2}$-except that the debate comes at a critical moment in the response to covid-19. ${ }^{3}$ It is a debate being played out in most countries and is simply this: what is the best strategy for the second surge in covid-19 infections?

We are still learning about covid-19. Fear was a factor in the initial response, and patients might have been better served by "ordinary decision making in extraordinary times." ${ }^{4}$ In the meantime, the evidence base for treatments, such as convalescent plasma and remdesivir, continues to grow. ${ }^{56}$ Management approaches in pregnancy, for example, are better informed. ${ }^{7} 8$

Clinicians are establishing new normals in primary care and for treating complex illnesses such as multiple sclerosis. ${ }^{910}$ Universities and medical schools are struggling with the financial effects of covid-19. ${ }^{11}$ The business as usual of workforce planning, coping with emergency unit referrals, and drug side effects remains challenging enough. ${ }^{12-14}$

The hope is that the second innings of covid-19 will be less deadly, but that hope is undermined in the UK by a failed test and trace programme. ${ }^{15}$ Experience from Asia is that effective testing and contact tracing, combined with physical distancing measures, keep an economy open. Health is the key to wealth.

But England's test and trace regime is a mess; plans to reopen schools, universities, and workplaces are an orchestrated chaos. The consequent rise in new infections has breached testing capacities at commercial testing facilities. ${ }^{1617}$ It is this central and ongoing failure, combined with the government's mixed messaging, that raises the spectre of another lockdown or "circuit break." ${ }^{18}$ Wealth, it turns out, is hard to achieve without health.

Reasonable questions are being asked about the health and economic impacts of any form of second lockdown. But what is the alternative in the absence of an effective test and trace system? A strategy that tolerates a build-up of herd or population immunity is speculative, bound to overwhelm health services, likely to impact on long term health, and potentially deadly. ${ }^{19}$

Sweden, the poster child of herd immunity, may eventually tell a different story. T cell immunity may prove to be key to limiting illness and death from covid-19. ${ }^{20}$ But it is too early to reach those conclusions on the basis of science, however intellectually seductive. The sensible alternative is caution, the precautionary principle. It is a message that chief scientists and medical advisers are now rightly delivering to politicians.
Anthony Fauci, the US government's lead adviser on infectious diseases, has an impressive track record in speaking truth to power, as he explains in a wide ranging interview. ${ }^{21}$ What Fauci learnt is that political leaders have respect for you if you base your advice on science and don't shy away from telling them what they don't want to hear: "Whether they act on the things you tell them," says Fauci, "is beyond my power."

1 Wise J. Covid-19: Experts divide into two camps of action-shielding versus blanket policies. BM/2020;370:m3702. doi: 10.1136/bmj.m3702 pmid: 32958467

2 Oliver D. David Oliver: Why polarise healthcare opinions?BMJ 2020;370:m3620doi: 10.1136/bmj.m3620.

3 lacobucci G. Covid-19: New restrictions to curb rising infection rate are set throughout UK. BMJ 2020;370:m3712 doi: 10.1136/bmi.m3712 pmid: 32962987

4 Burman R, Cairns R, Canestrini S, etal. Making ordinary decisions in extraordinary times. BMJ2020:370:m3268. doi: 10.1136/bmj.m3268 pmid: 32847805

5 Estcourt LJ, Roberts DJ. Convalescent plasma for covid-19. BMJ 2020;370:m3516. doi: 10.1136/bmj.m3516 pmid: 32933945

6 Rochwerg B, Agarwal A, Zeng L, etal. Remdesivir for severe covid-19: a clinical practice guideline. BM/2020;370:m2924 doi: 10.1136/bmj.m2924 pmid: 32732352

7 Allotey J, Stallings E, Bonet M, etalfor PregCOV-19 Living Systematic Review Consortium. Clinical manifestations, risk factors, and maternal and perinata outcomes of coronavirus disease 2019 in pregnancy: living systematic review and meta-analysis. BMJ2020;370:m3320. doi: 10.1136/bmi.m3320 pmid: 32873575

8 Pirkle CM. Evidence based care for pregnant women with covid-19. BMJ 2020;370:m3510. doi: 10.1136/bmj.m3510 pmid: 32907823

9 Marshall M. Now is the time to support general practice, not demoralise GPs. BMJ Opinion. 17 Sep 2020 https://blogs.bmj.com/bmj/2020/09/17/martin-marshall-now-is-the-timeto-support-general-practice-not-demoralise-gps.

10 Giovannoni G, Thomson A, Horne R. Covid-19-induced changes in the management of multiple sclerosis. BMJ Opinion. 14 Sep 2020. https://blogs.bmj.com/bmj/2020/09/14/covid-19-induced-changes-in-themanagement-of-multiple-sclerosis.

11 Armstrong S. UK medical schools fear for quality of student education as funding axe falls. BMJ2020;370:m3656doi: 10.1136/bmj.m3656.

12 Bailey S. The NHS people plan. BMJ2020;370:m3398. doi: 10.1136/bmj.m3398 pmid: 32895224

13 Salisbury H. Helen Salisbury: Plan your emergency. BM/2020;370:m3612. doi: 10.1136/bmj.m3612 pmid: 32962990

14 McGettigan P, Ferner RE. Painful perianal ulcers with nicorandil. BMJ 2020;370:m3351. doi: 10.1136/bmj.m3351 pmid: 32933904

15 Deeks JJ, Brookes AJ, Pollock AM. Operation Moonshot proposals are scientifically unsound. BMJ2020;370:m3699. doi: 10.1136/bmi.m3699 pmid: 32963111

16 Mathew R. Rammya Mathew: "Back to school" must be backed by a functioning covid-19 testing programme. BMJ2020;370:m3614. doi: 10.1136/bmj.m3614 pmid: 32943385

17 Wise J. Covid-19: What's going wrong with testing in the UK?BMJ 2020;370:m3678. doi: 10.1136/bmj.m3678 pmid: 32958475

18 lacobucci G. Sixty seconds on ... circuit break. BMJ 2020;370:m3686. doi: 10.1136/bmj.m3686 pmid: 32958462

19 Greenhalgh T, Alwan NA, Bogaert D, et al. Covid-19: An open letter to the UK's chief medical officers. BMJ Opinion. 21 Sep 2020. https://blogs.bmj.com/bmj/2020/09/21/covid-19-an-open-letter-to-theuks-chief-medical-officers.

20 Doshi P. Covid-19: Do many people have pre-existing immunity?BMJ 2020;370:m3563. doi: 10.1136/bmj.m3563 pmid: 32943427

21 Godlee F, Silberner J. The BMJ interview: Anthony Fauci on covid-19. BM 2020;370:m3703doi: 10.1136/bmj.m3703. 
This article is made freely available for use in accordance with BMI's website terms and conditions for the duration of the covid-19 pandemic or until otherwise determined by BMJ. You may use, download and print the article for any lawful, non-commercial purpose (including text and data mining) provided

that all copyright notices and trade marks are retained. 